\title{
СТРАТЕГИЧЕСКИЙ ПОДХОД К РАЗВИТИЮ НАЦИОНАЛЬНОЙ ГЕОПОЛИТИЧЕСКОЙ ЭКОНОМИКИ
}

\begin{abstract}
Аннотация. Предметом статьи выступает геоэкономикология как методическая основа геополитической экономики государства. Объект статьи - стратегия развития национальной геополитической экономики. Целью настоящей статьи является формирование стратегии развития геоэкономикологии как методической основы построения геополитической экономики страны в условиях выхода из глобального кризиса. Для достижения поставленной чели решаются такие задачи: - исследуется понятие и содержание стратегии развития геополитической экономики;- исследуются понятие, содержание и спечифические черты геополитической экономики сучетом наблюдаемого в 2015 году глобального геополитического кризиса; -формируются основы геоэкономикологии как науки огеополитической экономике и геоэкономического механизма; -исследуются особенности геоэкономической конкуренции с учетом прогнозируемых вариантов посткризисного мирового порядка и влияние мирового порядка на геополитисческую экономику; -исследуются факторы, влияющие на степень успешности развития национальной экономики. Методами исследования выступают исторический ретроспективный анализ, логический анализ, сравнительный анализ, логическое прогнозирование, лингвистический подход в анализе, совместный анализ Новизна исследования заключается в том, что в нем поставлены и решены такие научные задачи: исследуется понятие и содержание стратегии развития геополитической экономики; исследуются понятие, содержание и специфические черты геополитической экономики сучетом наблюдаемого в 2015 году глобального геополитического кризиса; формируются основы геоэкономикологии как науки о геополитической экономике игеоэкономического механизма; исследуются особенности геоэкономической конкуренции сучетом прогнозируемых вариантов посткризисного мирового порядка и влияние мирового порядка на геополитисческую экономику; -исследуются факторы, влияющие на степень успешности развития национальной экономики.
\end{abstract}

Ключевые слова: стратегия, кризис, геополитика, управление, методика, анализ, глобализация, инструменты, экономика, геоэкономика.

Аннотация. Geoeconomicology as a methodical basis of geopolitical economy of the state is the subject of this study. The object of this study is the strategy of national geopolitical economy's development. The goal of this article is to form a strategy for developing geoeconomicology as a methodical basis for developing the country's geopolitical economy in the conditions of exiting global crisis. In order to achieve this, the author resolves the following tasks: -to study the definition and content of the strategy of geopolitical economy's development; -to study the definition, content and defining traits of geopolitical economy, considering the evident 2015 global economic crisis; -to form the basis of geoeconomicology as a science on geopolitical economy and a geoeconomical mechanism; -to research the defining traits of geoeconomic competition, considering the projected variants for post-crisis world order, and the influence of world order on geopolitical economy; -to research the factors that impact the success of national economies. The methods of this research include historical retrospective analysis, logical analysis, comparative analysis, logical projections, linguistic approach, joint analysis. The novelty of this research is based on the fact that it sets and solves the scientific tasks of studying the definition and content of the strategy of geopolitical economy's development, the definition, content and defining traits of geopolitical economy, considering the evident 2015 global economic crisis, forming the basis of geoeconomicology as a science on geopolitical economy and a geoeconomical mechanism, researching the defining traits of geoeconomic competition, considering the projected variants for post-crisis world order, and the influence of world order on geopolitical economy, researching the factors that impact the success of national economies.

Ключевые слова: tools, globalization, analysis, technique, management, geopolitics, crisis, strategy, economy, geoeconomy.

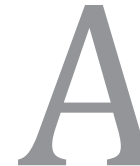

ктуальность настоящей статьи определяется тем, что в 2015 году практически определилась степень зависимости национальной экономики от геополитической ситуации в связи с тем, что серьезно усложнилось обстановка в сфере международных геополитических и экономических отношений России с другими странами. Актуальность развития геоэкономики повышается в связи с тем, что сопредельные страны успешно практикуют развитие своей геоэкономики, например, в виде известных трансрегиональных транспортных проектов.

Все это проявляет тесную взаимосвязь геополитики, которая все в большой степени влияет на экономику и, наоборот экономика влияет на геополитические возможности государства. Поэтому на классификацию и оценку деятельности отдельных отраслей национальной экономики должен быть более широкий -геоэкономический взгляд на содержание и результаты экономической деятельности. Все больше факторов указывает на то, что максимизация текущей прибыли не может быть единственным критерием оценки экономической деятельности государством, обществом, руководством корпораций. Руководители крупных транснациональных финансовых и корпоративных объединений все больше понимают, что они 


\section{Тренды и управление 3(11) • 2015}

не могут игнорировать геополитический риск. В начале сентября 2015 года в СМИ признают, что геополитический риск экономической деятельности стал наиболее значимым с периода Второй мировой войны.

Все это может показывать необходимость принятия стратегии развития геополитической экономики в нашей стране.

Целью настоящей статьи является формирование стратегии развития геоэкономикологии как методической основы построения геополитической экономики страны в условиях выхода из глобального кризиса.

Для достижения поставленной цели решаются такие задачи:

- исследуется понятие и содержаниестратегии развития геополитической экономики;

- исследуются понятие, содержание и специфические черты геополитической экономики с учетом наблюдаемого в 2015 году глобального геополитического кризиса;

- формируются основы геоэкономикологии как науки о геополитической экономике и геоэкономического механизма;

- исследуются особенности геоэкономической конкуренции с учетом прогнозируемых вариантов посткризисного мирового порядка и влияние мирового порядка на геополитисческую экономику;

- исследуются факторы, влияющие на степень успешности развития национальной экономики.

Объект статьи-стратегия развития национальной геополитической экономики.

Предмет статьи- геоэкономикология как методическая основа геополитической экономики.

Как известно термин «стратегия» переводится на русский язык как мастерство генерала. Стратегический подход в экономике начал активно развиваться начиная с 1965 по мере повышения ресурсоемкости инновационных и инвестиционных проектов. Стратегический подход подразумевает планирование развития крупного бизнеса или экономики государства на длительный период.

Стратегией развития геополитической экономики предлагается называть совокупность мероприятий, направленных на длительную перспективу имеющих своей целью создания геополитического сектора национальной экономики. Для формирования такой стратегии нужно:

- $\quad$ определить стратегические интересы в развитии национальной геополитической экономики;

- $\quad$ предложить систему мер направленных на развитие национальной геополитической экономики;

- $\quad$ определить ресурсы, сроки их использования и ответственность за достижение целей стратегических мероприятий по формированию национальной геополитической экономики;

- обосновать критерии успешности развития национальной геополитической экономики;

- определить критерии и сроки пересмотра и корректировки стратеги развития национальной геополитической экономики.

Эта работа требует формирования методологии развития национальной геополитической экономики.

Геополитическая экономика или сокращенно геоэкономика (англ. geoеconomics) - это относительно новый структурный элемент одновременно геополитики и глобальной экономики. Геоэкономика рассматривает геополитические процессе с позиций их тесной системной связи с экономической деятельностью геополитических субъектов. В предмет изучения геоэкономики входят процессы экономического развития в определенных геополитических условиях не только государственных и региональных образований, но и глобальных, региональных международных экономических, финансовых и интеграционных объединений, транснациональных корпораций, транспортных поясов, свободных экономических зон, а также различных геополитических субъектов (или блоков).

Необходимость формирования геоэкономики возросла в связи с кризисом 2008 года. Этот кризис -кризис глобального постиндустриального мира, который имеет особенности, связанные со спецификой состояния и противоречиями глобального мира в начале 21 века. 


\section{Экономическое управление}

Постиндустриальную глобализацию мировой экономики рассматривают как процесс усиления взаимосвязей и взаимной зависимости в современном мире путем развития и структуризации мировой экономики и рынков, средств коммуникаций, транспортных систем, новых информационных технологий в рамках транснациональных корпораций (ТНК) и др. Часть экспертов считает, что причины глобализации сложны и не до конца понятны [1].

Вместе с тем, анализ возможных причин глобализации дает основания считать, что причиной глобализации является рост ресурсоемкости инноваций (инновационная гипотеза глобализации). Данная гипотеза базируется на том, что в начале 21 века инновации являются крайне ресурсоемкими. Такие дорогие инновационные проекты (например, самолет A-380) могут давать положительный финансовый результат только в условиях глобального рынка. Для ресурсоемких инновационных проектов емкости национального рынка недостаточно для того, чтобы получить положительный финансовый результат -прибыль от инноваций [2].

При исследование геоэкономики в рамках инновационной гипотезы глобализации нужно учитывать, что предметом совокупных спроса и предложения в мировой экономике является товар, который трактуется как вся совокупность материальных и нематериальных предметов, предлагаемых для продажи [2]. В международной торговле товары делятся на торгуемые и неторгуемые. Торгуемые товары могут перемещаться между различными странами в процессе международной торговли. Обращение и потребление неторгуемых товаров происходит в том же достаточно локальном регионе, где они произведены.

Деление товаров на торгуемые и неторгуемые закреплено Стандартизованной промышленной классификацией ООН. В рамках этой классификации все существующие товары и услуги делятся на девять больших групп. В группу торгуемые товары входят: сельское хозяйство, охота, лесное хозяйство и рыболовство, добывающая и обрабатывающая промышленность. В группу неторгуемых товаров входят: коммунальные услуги и строительство; оптовая и розничная торговля, и др.
Границы между торгуемыми и неторгуемыми товарами весьма условны, а основные отличия между торгуемыми и неторгуемыми товарами состоят в следующем. Во-первых, цены на торгуемые товары определяются соотношением спроса и предложения на глобальном рынке и находятся под их влиянием как внутри страны, так и за рубежом. Цены на неторгуемые товары определяются только соотношением спроса и предложения на национальном внутреннем рынке. Колебания цен на аналогичные неторгуемые товары в других странах на внутренних ценах не отражаются. Во-вторых, поддержание баланса внутреннего спроса и предложения на торгуемые товары не настолько важно, как для неторгуемых товаров. В-третьих, уровень и динамика внутренних цен на торгуемые товары часто следует за аналогичными показателями в глобального рынка, других странах. Торгуемые товары делятся на экспортируемые и импортируемые.

Глобальный (мировой) рынок выступает как завершающая форма мировой экономики, которая представляет собой сферу устойчивых товарно-денежных отношений между странами, основанных на международном разделении труда. Предметом конкуренции на глобальном рынке считают товар или услугу производимых фирмами-соперниками для завоевания рынка. Выделяют ценовую и неценовую конкуренцию. Кроме того, в рыночной экономике выделяют еще два типа конкуренции - внутриотраслевую (отраслевую) и межотраслевую.

Понятие геоэкономики, в связи с его относительной новизной не является общепризнанным и устоявшимся. Поэтому логично исследовать возможные трактовки и содержание этого понятия.

Один из возможных подходов к трактовке понятия геоэкономики может состоять в том, что национальная экономика может быть представлена в виде совокупности национальной геоэкономики и национальной внутренней (местной) экономики. Национальной геоэкономикой можно назвать ту часть экономики, в раках которой разрабатываются, производятся, обращаются, используются и утилизируются торгуемые товары и услуги. Национальной 


\section{Тренды и управление 3(11) • 2015}

внутренней (местной) экономикой можно назвать ту часть экономики, в раках которой разрабатываются, производятся, обращаются, используются и утилизируются не торгуемые товары и услуги. Неторгуемые товары не перемещаются и не участвуют в международной торговле, они потребляются в стране, где они произведены. Заметим, что при таком подходе внутренняя экономика имеет геополитическое значение, поскольку обеспечивает демографическое развитие и удовлетворение потребностей населения страны.

В 2015 году можно говорить о существовании глобальной конкуренции на рынках торгуемых высокотехнологичных товаров, которая может характеризоваться такими особенностями:

- постоянной трансформации деления товаров и услуг на торгуемые и неторгуемые товары и услуги в условиях глобализации, открытости границ, развития информационных технологий и транспортных систем;

- сложностью определения границ и суммарной емкости рынка для конкретного высокотехнологичного товара, что повышает рыночный риск;

- возможностью абсолютно непредвиденного и неуправляемого изменения емкости рынка в результате санкций, эмбарго, моратория платежа и других проявлений геополитического риска;

- в глобальной рыночной конкуренции участвуют государства посредством проведения определенной экономической и промышленной политики, создания институциональной системы поддержки и развития инновационной и инвестиционной деятельности, а так же путем осуществления денежно-кредитного и валютного регулирования;

- субъектами олигополистической конкуренции на глобальном рынке высокотехнологичных товаров чаще всего выступают транснациональные корпорации или их подразделения, число которых трудно определить заранее, в частности по причине коммерческой тайны;

- в глобальной конкуренции принимают участие разработчики и производители товаров различных стран, деятельность в которых отличается различными конкурентными преимуществами и недостатками, связанными, в частности, со страной базирования;

- технические требования к реализации потребительских свойств товаров и услуг формируются на основе международных технических и социальных стандартов определенных социальных групп потребителей;

- цены на торгуемые товары устанавливаются на мировом рынке на основе конкуренции производителей, достижения баланса спроса и предложения, с учетом валютных курсов стран базирования;

- $\quad$ взаимоотношения конкурирующих производителей из различных стран, а также производителей и потребителей на глобальном рынке регулируются не только национальным, но и международным законодательством, конвенциями, договорами;

- $\quad$ международные организации рекомендуют своими нормативными актами базисные условия поставки и расчетов между продавцами и покупателями, которые определяются договоренностями сторон сделки;

- $\quad$ в связи с тем, что участники международных торговых сделок чаще всего являются резидентами различных государств, то для разрешение споров и конфликтов между ними приходится прибегать к обращению в международные судебные органы и др.

При этом возможны еще и другие трактовки понятия геополитической экономики. Во-вторых, под геополитической экономикой (геоэкономикой) можно понимать еще и такую экономику, которая ориентирована на достижение определенных перспективных геополитических целей государства. В-третьих, под геоэкономикой можно понимать и такую экономику, которая минимизирует геополитический риск, риск потери конкурентоспособности государства, риск распада государства по любой из причин (демография, социальная структура, технологический уровень экономики и др.).

В 2015 году при анализе геоэкономики нужно учитывать, что это первый глобальный кризис, в котором транснациональные корпорации 
конкурируют в глобальном управлении с государствами. При этом государства в результате политики открытости в условиях глобального мира в начале 21 века имеют черты общественных публичных корпораций $[3,4]$.

Наблюдения (мониторинг) за практикой глобального антикризисного управления показывают, что практика глобального антикризисного управления не всегда соответствует теоретическим положениям и получает все более конфронтационный характер.

В такой сложной ситуации возрастает значение создания целостной научной теории, которая способна оптимизировать развитие геополитической экономики (геоэкономики). Именно на основе такой развитой теории -геоэкономикологии-науки возможно опережающее отражение геополитических экономических явлений, прогнозирование и научное обоснование возможных геополитических антикризисных мер.

Для развития геоэкономики в таких сложных условиях требуется некая методическая основа. Предлагается назвать геоэкономикологией - науку о геополитической экономике, включая глобальное антикризисное управление экономикой.

В связи с повышением роли геополитики в социальных и экономических процессах в 2015 году интенсивно развивается наука о геополитике - геополитикология тесно взаимосвязаны [5]. Геоэкономикология и геополитикология тесно взаимосвязаны. Геоэкономикология может представлять собой пересечение и/или область системной взаимосвязи геополитикологии и экономической теории (политэкономии).

Геоэкономикология в широком ее понимании - это наука о мировых экономических отношениях, и влиянии системы международных экономических отношений на геополитические процессы, организации и функционировании глобальной системы экономического управления, субъектах и объектах глобального экономического управления.

Развивая геоэкономикологию и геополитикологию нужно учитывать, что современная национальная экономика отражает расстановку геополитических сил на международной и внутриполитической арене, а поэтому получает геополитическую составляющую и название -геоэкономика (геополитическая экономика). При этом нужно учитывать и то, что эксперты выделяют три составляющие современной национальной экономики и социальной сферы: государство; бизнес; гражданское общество.

Для формирования геоэкономикологии как развиваемой новой научной дисциплины сформулируем ее объект, предмет, функции и роли таким образом. Объект геоэкономикологии представляет собой исследуемую сферу деятельности. В объект геоэкономикологии входят устройство мировой экономической системы (в ее связи с географическим особенностями регионов), мировые рынки товаров и услуг, международные денежно-кредитные и товарно-денежные отношения, органы и инструменты глобального экономического управления. Экономический мировой порядок можно определить как наблюдаемое устройство мировой экономической системы, включая деятельность органов глобального экономического управления (ВТО, МВФ, ОЭСР и др.).

Предметом геоэкономикологии могут быть определенные закономерности организации и функционирования мирового экономического (включая финансовый) порядка, субъектов глобального экономического и финансового управления, роль национального государственного экономического управления в обеспечении геополитической субъектности и конкурентоспособности государства.

Геоэкономикология как наука о мировом влиянии геополитики на экономику (и наоборот влиянии экономики на геополитику) должна развивается как целостная система теоретического и прикладного знания об объектах, субъектах, инструментах глобального экономического управления. Геоэкономикология изучает влияние экономики на весь комплекс процессов жизнедеятельности и на такие характеристики жизнедеятельности как геополитическая специализация, эффективность, затраты, риски, время реализации экономических процессов во всех сферах государства и др.

Научный метод геоэкономикологии - это система принципов и приемов, с использованием 


\section{Тренды и управление 3(11) • 2015}

которых обеспечивается объективное познание объективной действительности функционирования сложной мировой экономической системы, связи экономики с геополитическими процессами. Методом геоэкономикологии условимся называть совокупность принципов и приемов, с применением которых достигается снятие неопределенности, объективное познание мирового экономического порядка.

Сущность геоэкономикологии как науки о мировом экономическом порядке и геополитическом (глобальном) управлении экономикой отражают функции и роли этой науки. Социально-экономическая роль и значимость геоэкономикологии вытекает из результатов реализации тех функций, которые эта наука выполняет в отношении удовлетворения потребностей глобального гражданского общества, мировой экономики и национальных государств. При исследовании функций геоэкономикологии нужно учитывать, что эти функции должны находиться в смстемной связи с функциями государства и права, а так же функциями глобальных и национальных общественных и предпринимательских корпораций.

Можно выделить такие функции геоэкономикологии: философского обеспечения; методологическая, познавательная, инструментальная, прогностическая, нормативная, идейно-воспитательная, предупредительная, социализации знаний по геоэкономикологии.

Для геоэкономикологии функция философского и идеологического обеспечения функционирования мирового экономического порядка и глобального экономического управления, экономического обеспечения жизнедеятельности населения состоит в разработке, системном объединении и своевременной адаптации в условиях глобализации философии, идеологии, политики построения мирового порядка и системы глобального управления, функционирования субъектов и объектов государства.

Философия экономического мирового порядка и системы глобального финансовоэкономического управления - это система наиболее общих, основополагающих взглядов на сущность, принципы функционирования и развития, практическое предназначение эконо- мического мирового порядка и государства, как части мирового порядка.

Идеология системы глобального экономического управления, соответственно, представляет собой ключевые идеи, развития экономического мирового порядка, распределение экономической власти.

Политика экономического мирового порядка и системы глобального экономического управления - это разрабатываемая на основе его философии и идеологии система мер и воздействий на экономические процессы происходящие в мировой экономической системе, глобальном экономическом управлении, во внутренней и внешней экономической среде государства, глобальной и национальной экономической элите процессы.

Геополитика представляет собой результат взаимодействия воли глобальной и воли национальных элит в форме системы геополитических и национальных мероприятий, направленных на совершенствование и повышение эффективности процессов глобального управления, развитие глобальной экономики.

Методологическая функция геоэкономикологии состоит в формировании теоретических основ и методологии исследования внешней и внутренней среды мировой экономической системы и системы глобального экономического управления, глобального бизнеса, формулировании законов и категорий геоэкономикологии.

Познавательная функция геоэкономикологии охватывает процессы накопления, описания, изучения фактов экономической действительности, связанных с внешней и внутренней средой глобального экономического управления, анализе социально-экономических ситуаций в мире, выявление важнейших проблем и противоречий устойчивого экономического развития мировой экономической системы.

Регулятивная (инструментальная) функция геоэкономикологии заключается в выработке практических рекомендаций для органов международного (глобального) экономического, корпоративного предпринимательского, государственного экономического управления.

Прогностическая функция геоэкономикологии охватывает методы вероятностного сужде- 
ния и оценок состояния мировой экономической системы в будущем.

Законотворческая (нормативная) функция геоэкономикологии -продукт геополитики - состоит в совершенствование систем международного экономического и предпринимательского права, закрепляет в форме законов и других нормативных актов обязательную для исполнения в экономике волю международной экономической элиты.

Идейно-воспитательная, мировоззренческая функция геоэкономикологии сводится к формированию, обосновании определенных международных экономических идеалов и ценностей, обеспечивающих эффективность глобального экономического режима, развитии культуры корректных международных экономических отношений в гражданском обществе, на глобальном уровне управления экономикой.

Мировоззренческая (идейно-воспитательная) функция геоэкономикологии тесно взаимодействует с геокультурными процессами и геокультурной безопасностью [6].

Предупредительная функция геоэкономикологии заключается в определении рисков устойчивого развития мировой экномической системы управления, бизнеса, различных источников риска в экономике.

Функция социализации в геоэкономикологии состоит в подготовке знаний о мировом экономическом порядке, функционировании органов глобального экономического управления к ихусвоению и практическому использованию функционерами международных финансовых и экономических организаций, дипломатическими работниками, оборонными ведомствами, депутатами различныхуровней, представителями бизнеса, бизнесом и гражданским обществом в целом.

Роли геоэкономикологии представляют собой полезные (или вредные) последствия, результаты использования научных методов этой науки в геоэкономике и экономической практике бизнеса.

Для государства роль геоэкономикологии заключается в снижении геополитического риска и методическом обеспечении формирования экономической политики государства с учетом его геополитических интересов, снижения вероятности попадания под санкции или втягивания в международные геоэкономические конфликты.

Для глобальных и национальных корпоративных субъектов социально-экономической деятельности роль науки о геоэкономике заключается в снижении геополитического и политического риска экономической деятельности и обеспечении благоприятных условий устойчивого социально-экономического развития деятельности этого бизнеса, субъекта, признания этого субъекта национально и социально ответственным.

1. Геополитика и экономика тесно связаны: геополитическое положение государства влияет на экономические возможности и степень геополитического риска корпораций, а уровень технологического развития корпораций влияет на геополитическое положение государства;

2. Различные отрасли экономики в различной мере влияют на геополитическое положение государства;

3. Отрасли национальной экономики должны рассматриваться не только с точки зрения их влияния на ВВП государства, но и их влияния на геополитическое положение и устойчивость государства;

4. Основные черты мирового геополитического и геоэкономического порядка определяются такими факторами: уровень развития производительных сил общества, уровень сложности хозяйственно-экономической деятельности, необходимый для экономического развития уровень прав и свобод акторов экономической и социальной жизни.

5. Геополитическая и геоэкономическая «ловушка» для сепаратистски настроенных развитых технологически регионов государства заключается в том, что выходя с конфликтом из метрополии они автоматически теряют рынки сбыта своей продукции, что делает их потенциал избыточным и приводит к обвалу экономики региона.

6. Все отрасли национальной геоэкономики представляют собой «технологическую пирамиду» и в их совокупности определяют геоэкономическое положение государства. 


\section{Тренды и управление 3(11) • 2015}

7. С геоэкономической точки зрения государство может характеризоваться как производственная и экономическая система, совокупность потребительских рынков и социальная система.

8. Механизм геоэкономической оптимизации размеров государства или союза государств (геополитического субъекта) заключается в противоречии между стремлением увеличить рынки сбыта для создания эффекта масштаба у национальных производителей и необходимостью поддержания экономически не обоснованных высоких социальных стандартов жизни и через завышение стоимости валюты субсидировать менее развитые регионы такого сложного геополитического субъекта.

9. Острые геополитические и одновременно геоэкономические конфликты (войны), которые, как известно, исторически рассматриваются как продолжение политики другими средствами, могут возникать в связи с невозможностью разрешения внутренних противоречий в государствах-участниках конфликта, как правило приводят к реструктуризации элиты, политического и экономико-технологического базиса участвующих в геополитическом конфликте государств.

10. Острые геополитические и одновременно геоэкономические конфликты (войны) начинаются, ведутся и заканчиваются по законам, отличным от законов мирного времени, а именно по законам войны.

Содержание и роль геоэкономической деятельности зависит и переплетается с мировым геополитическим порядком. При этом до настоящего времени типология мировых порядков остается мало изученной темой в современной теории международных отношений, что делает вопрос структуры мирового порядка крайне актуальным [7].

Ретроспективный анализ позволяет выделить исторически такие мировые порядки и принципы их формирования.

1. Общинно - удельный (княжеский) мировой порядок существовал в процессе создания национальных государств до начала средних веков. В этот период товарно-денежные отношения были развиты слабо, была преимущественно на- туральная экономика. Геополитические условия таковы, что частые войны между отдельными княжествами привели к необходимости защиты от внешней угрозы. Наиболее геополитически, военно сильные государства смогли создать свои империи.

2. Имперский мировой порядок существовал со средних веков до начала 20-го века). Он характеризуется наличием небольшого (4-6) количества крупных многонациональных империй. Империи были способных защитить от внешнего врага свои территории. Одновременно для подданных были созданы общие условия финансово-хозяйственной деятельности, эффективные системы налогообложения и правосудия.

3. Экономический блоковый мировой порядок существовал между первой и второй мировыми войнами (золотой блок-Франция; стерлинговый блок -Великобритания; долларовый блок - США). Геополитический блоковый мировой порядок оформился уже после Второй мировой войны. Каждый из геополитических блоков возглавляла стана имевшая свою идеологию и мощную экономическую систему (США $-50 \%$ мирового ВВП, а СССР-20\%). Вероятно по причине изменения доли ведущих стран в мировом ВВП блоковый (а тем более имперский) мировой порядок после кризиса 2008 года уже не могут развиваться.

4. Известно мнение, что в 21 веке геополитическое положение государства определяется и создается в сфере науки и технологий [8,с.34]. Вероятно четвертый мировой порядок будет носить геоэкономический характер, более демократическим. Предположительно это будет демократический мировой порядок на основе национального суверенитета государств, добровольного объединения стран в экономические союзы на основе геополитических и экономических интересов, с использованием активных консультаций, коллегиального принятия решений участниками союзов, совместного участие в мировом разделении труда.

При геоэкономическом подходе в качестве геополитических сегментов могут рассматриваться не только геополитические пространства, но и технологические ниши в международном разделении труда, связанные с разработкой 
и производством определенных групп товаров и услуг.

В каждом из сложившихся геополитических и геоэкономических сегментов (объединении тяготеющих друг к другу государств) отношения между суверенными странами могут строиться, как на основе специализации национальных экономик, геоэкономическом лидерстве государства. Геоэкономическое лидерство государства состоит в возможности выдвинуть вдохновляющу программу совместного социальноэкономического развития нескольких стран и их корпораций, сформировать видение, а потом и программу такого совместного развития. В таком геоэкономическом лидерстве стран возрастает значение научного, технологического лидерства, высокий уровень образования.

На основе изменений лидерских позиций государств возможна оптимизация как размеров самих государств, так и союзов государств. Возможный алгоритм такой оптимизации может быть получен на основе совместных данных геоэкономикологии и исследования геоэкономического механизма. Геоэкономический механизм представляет собой совокупность способов и инструментов влияния экономических процессов и их результатов на геополитический процесс.

Анализ содержания геоэкономического механизма позволяет утверждать, что включение новых территорий в составное государство (союз) оправдано до тех пор пока эффект масштаба (снижение себестоимости продукции, а следовательно, и увеличение прибыли, при увеличении объемов производства) производства для экономики метрополии (ядра межгосударственного образования) от включения новой территории превышает фактическое субсидирование этой (новой присоединенной) территории за счет расширения обращения национальной валюты метрополии имеющей более высокий уровень производительности труда (а следовательно, и более дорогой), чем на присоединяемой к государству территории [9].

В рамках геоэкономикологии должны исследоваться совместно и в системной связи геополитическая и экономическая конкуренция национальных экономик, с учетом международного разделения труда. При геоэкономикологиических исследованиях нужно принимать во внимание, что такая конкуренция существует не столько между странами, сколько между транснациональными воспроизводственными системами, которые существуют в рамках объединения стран определенной категории. Такие транснациональные системы объединяют национальные системы образования, развития науки, накопления капитала и транснациональные производственные и финансовые системы в масштабах мирового рынка, включая ТНК, глобальные финансовые монополии, наднациональные органы геополитического и экономического регулирования.

Страны, не входящие в мировую элиту, образуют периферию. Они вынуждены платить интеллектуальную ренту, которая аккумулируется в импортируемых другими странами товарах и услугах [10].

В рамках геоэкономикологии при анализе глобальной конкуренции в могут применяться ряд понятий (сравнительные преимущества; конкурентные преимущества, конкурентная позиция, стратегия, сечение; силы конкуренции и др.). В рамках геоэкономики сравнительные преимущества определяются тем, что производство товаров характеризуется относительными преимуществами или недостатками, которые различны для определенных государств. При этом производителям товаров конкретных государств экономически выгодно специализироваться на производстве определенных товаров и импортировать иные товары. Поэтому государство имеет возможность получить выгоды, если будет концентрировать свои ресурсы в областях, где их сравнительные преимущества больше.

Конкурентные преимущества включают все то, что позволяет обеспечить победу в конкурентной борьбе (лучшие потребительские свойства и качество товара, более эффективное производство, хорошо поставленная реклама, лучшая система сбыта, обладание патентами и др.).

Конкурентная позиция определяет то положение, которое корпорация занимает в своей отрасли (или глобальной мировой экономике) на основании полученных ею результатов деятельности с присущими ей преимуществами и недостатками по сравнению с конкурентами. 


\section{Тренды и управление 3(11) • 2015}

Конкурентную стратегию корпорации часто называют синонимом его деловой стратегии. Конкурентная стратегия включает совокупность правил, которым должно следовать любое хозяйственное подразделение корпорации, преследующее достижение и поддержание конкурентоспособности в соответствующей отрасли экономики или на глобальном рынке.

Конкурентное сечение представляет информацию об организации, отобранную и структурированную таким образом, чтобы выявить и провести сравнительный анализ факторов, определяющих ее конкурентную позицию.

Силыконкуренции включают факторы, влияющие на конкурентную позицию (внешние - экзогенные и внутренние- эндогенные).

Анализ конкуренции делают для того, чтобы оценить какие изменения в стратегии могут предпринять конкуренты. При этом М. Портер рассматривает четыре диагностические составляющие: будущие цели; предположения; текущая стратегия, возможности [2].

Понятие конкуренции в геоэкономике и геоконкуренции используется и в других сочетаниях, а именно, могут исследоваться сфера конкуренции, анализ конкурента, графы конкурента.

Кроме того в рамках геоэкономикологии нужно учитывать, что на геополитическую конкурентоспособность государства, его экономики большое влияние оказывает и успешная управленческая культура [11]. Для геоэкономической привлекательности государства, определяемой его прогрессивной управленческой культурой характерны такие черты.

1. Ориентация во времени: в прогрессивной геоэкономической культуре упор делается на будущее страны, а в статичных культурах делается упор на поиск аналогов проблем и светлых дней в прошлом и решение проблемы выживания в настоящем.

2. Отношение к работе: в геоэкономически успешных нациях успешный труд является основой жизненных достижений, материального благополучия, самоуважения; в отстающих нациях труд-это условие выживания, досадная необходимость.
3. Для геоэкономически успешных наций -бережливость есть путь к сбережению; для отстающих наций более характерны расточительство или равенство в бедности.

4. Хорошее образование в геоэкономически успешных нациях, необязательность этого в других - отстающих странах.

5. В успешных нациях -личные заслуги как основа повышения служебного и социального статуса; в отстающих странах основа этого: связи, коррупция, семейственность.

6. Социализация: в геоэкономически успешных нациях люди идентифицируют себя с большими общностями (страной, обществом и т.п.) распространение альтруизма и благотворительности; в отстающих странах - социализация в рамках семье, диаспоры, способствует непотизму, коррупции.

7. Этические нормы: в геополитически и экономически успешных нациях они более строги.

8. Закон и правосудие: в геоэкономически успешных нациях - незыблемые нормы для всех; избирательность правосудия.

9. Распределение власти: в геоэкономически успешных нациях-децентрализация, распределение, горизонтальные связи во власти; в отстающих странах - централизация и вертикальный характер связей во власти.

10. Светскость: религия отделена от государства в более геоэкономически успешных государствах.

В дополнение к этому зарубежные ученные активно работают над исследованием темы взаимоотношений государства, экономики, общества в геоэкономически успешных государствах, включая такие методические и культурные положения [11].

Первое. Для геоэкономически успешных государств характерно признание существования влияния специфики государственных институтов на экономическое развитие.

Второе. Открытые государства и общества более геоэкономически успешны потому, что способствуют экономическому росту больше, чем закрытые государства, которые создают ограниченные возможности.

Третье. Точно не ясно, какие именно институты и организации наиболее значимы 
для геоэкономических успехов государства и составляют демократические институты, обеспечивают обратную связь между государством и обществом, активно участвуют в противодействии коррупции.

Четвертое. Считают, что в настоящее время в геоэкономически успешных государствах нет «достаточно четких теорий о том, как развиваются институты открытого общества» [11]. Этот пробел в современном знании на влиянии гражданского общества на государство и экономику в определенной мере был заполнен работой [12].
В статье исследованы методические особенности геополитической экономики, развиваются методические положения науки о геоэкономике- геоэкономикологии, исследованы особенности геоэкономического механизма, геоэкономических конкурентных отношений, показано, что может потребоваться дальнейшее развитие методических положений геоэкономикологии в части геофинансов, международного кредита и других ее направлений, в частности геоэкономической управленческой культуры.

\section{Библиография}

1. Современная теория глобализации: экономические очерки/ Колл. ав торов под ред. Б.А. Денисова. - М., ГУУ, 2002, с.3-6.

2. Глущенко В.В. Риски инновационной и инвестиционной деятельности в условиях глобализации. -г. Железнодорожный, Московская область: ООО НПЦ Крылья, 2006. - 230 с.

3. Глущенко В.В. Корпорации как субъекты управления геополитическим риском инвестиционной деятельности в условиях глобализации М.: ГУУ, Вестник ГУУ, №1(14), 2006, с. 201-212

4. Глущенко В.В. Государство как геополитическая публичная корпорация в условиях постиндустриального глобального мира. М.: Национальные интересы: приоритеты и безопасность №7(16), 2007, с.15-25

5. Глущенко В.В. Геополитикология как научная основа геополитического прогнозирования// Международный научно-исследовательский журнал, №7 (38), 2015, Часть 4, Август, с.83-90.

6. Кузнецов В.Н. Геокультура. Основы геокультурной динамики безопасности в мире XXI. - M.: Книга и бизнес, 2003. - С. 8.

7. Сергеев В.М., Казанцев А.А. Структуры мирового порядка: историческая типология: М.: Космополис. - 2008. - №1(20), с. 6-10.

8. Бжезинский 3. Великая шахматная доска. Господство Америки и его геостратегические императивы. - М.: Международные отношения, 2003. - 250 с.

9. Глущенко В.В. Государствология и правология (наука о государстве и праве - общая теория государства и права): кризисология государства, государственное антикризисное управление. М.: ИП Глущенко Валерий Владимирович, 116 с.

10. Сапожникова Н.Т. Процесс глобализации и международные монополии / Современная теория глобализации: экономические очерки. - М.: ГУУ, 2002, с.63-75.

11. Государственное управление в 21 веке: повестка дня российской власти:10-я Международная научная конференция факультета государственного управления МГУ им. М.В. Ломоносова, 2931 мая 2012 г.Материалы в 3 ч. :Часть 1.-М.: Издательство Московского университета, 2013.-736 с.-(материалы конференций).

12. Глущенко В.В. Гражданология: введение в теорию гражданского общества - М.: ИП Глущенко Валерий Владимирович, 2009.-64 с.

13. Манойло А.В. Сирийский тупик «Арабской весны». // Вестн. Моск. Ун-та. Сер. 12. Политические науки. 2013. №6. С. 49-56.

14. Манойло А.В. Мирное разрешение конфликтов: национальные концепции, модели, технологии // Власть.-2008.-№8. - С.79-84. 


\section{Тренды и управление 3(11) • 2015}

15. Манойло А.В. Психологические операции: модели и технологии управления конфликтами. //Национальная безопасность nota bene. - 2009.-№1. - C.66-71.

16. Codagnone C., Filippov V. Equity, exit end national identity in a multinational federation: the "multicultural constitutional patriotism" project in Russia. // Journal of ethnic and migration studies. 2000. V. 26. №2.. P. 263-288.

17. Филиппов В.Р. Договорная федерация и эксклюзивная этничность // Федерализм. 2002 . №4. C. $185-216$.

18. И. В. Сурма, В. И. Аникин Современная Россия: методологические аспекты стратегии политического и экономического развития // Национальная безопасность / nota bene. - 2012. - 3. - С. 4 $-16$.

19. А. Г. Коряков Роль государства в обеспечении устойчивого развития отраслей экономики // Национальная безопасность / nota bene. - 2012. - 4. - С. 4 - 12.

20. Яник А.А. Управление социально-экономическими изменениями в условиях кризиса: что может дать России опыт Китая? // Право и политика. - 2014. - 12. - С. 1840 - 1848. DOI: 10.7256/1811-9018.2014.12.12940.

21. Абрамов Р.А. Региональная промышленная политика в структуре устойчивого функционирования территории. // Политика и Общество. - 2015. - 3. - C. 345 - 353. DOI: 10.7256/1812-8696.2015.3.14513.

22. Немцев И.А. Стратегия устойчивого развития как интеграционное ядро Евразийского союза // Политика и Общество. - 2015. - 2. - C. 198 - 213. DOI: 10.7256/1812-8696.2015.2.12298.

\section{References (transliterated)}

1. Sovremennaya teoriya globalizatsii: ekonomicheskie ocherki/ Koll. avtorov pod red. B.A. Denisova. - M., GUU, 2002, s.3-6.

2. Glushchenko V.V. Riski innovatsionnoi i investitsionnoi deyatel'nosti v usloviyakh globalizatsii.-g. Zheleznodorozhnyi, Moskovskaya oblast': 000 NPTs Kryl'ya, 2006. - 230 s.

3. Glushchenko V.V. Korporatsii kak sub"ekty upravleniya geopoliticheskim riskom investitsionnoi deyatel'nosti v usloviyakh globalizatsii M.: GUU, Vestnik GUU, №1(14), 2006, s. 201-212

4. Glushchenko V.V. Gosudarstvo kak geopoliticheskaya publichnaya korporatsiya v usloviyakh postindustrial'nogo global'nogo mira-M.: Natsional'nye interesy: prioritety i bezopasnost' №7(16), 2007, s.15-25

5. Glushchenko V.V. Geopolitikologiya kak nauchnaya osnova geopoliticheskogo prognozirovaniya// Mezhdunarodnyi nauchno-issledovatel’skii zhurnal, №7 (38), 2015, Chast' 4, Avgust, s.83-90.

6. Kuznetsov V.N. Geokul'tura. Osnovy geokul'turnoi dinamiki bezopasnosti v mire XXI. - M.: Kniga i biznes, 2003. - S. 8.

7. Sergeev V.M., Kazantsev A.A. Struktury mirovogo poryadka: istoricheskaya tipologiya: M.: Kosmopolis. - 2008. - №1(20),s. 6-10.

8. Bzhezinskii Z. Velikaya shakhmatnaya doska. Gospodstvo Ameriki i ego geostrategicheskie imperativy. - M.: Mezhdunarodnye otnosheniya, 2003. - 250 s.

9. Glushchenko V.V. Gosudarstvologiya i pravologiya (nauka o gosudarstve i prave-obshchaya teoriya gosudarstva i prava): krizisologiya gosudarstva, gosudarstvennoe antikrizisnoe upravlenie.-M.: IP Glushchenko Valerii Vladimirovich, $116 \mathrm{~s}$.

10. Sapozhnikova N.T. Protsess globalizatsii i mezhdunarodnye monopolii / Sovremennaya teoriya globalizatsii: ekonomicheskie ocherki. - M.: GUU, 2002, s.63-75.

11. Gosudarstvennoe upravlenie v 21 veke: povestka dnya rossiiskoi vlasti:10-ya Mezhdunarodnaya nauchnaya konferentsiya fakul'teta gosudarstvennogo upravleniya MGU im. M.V. Lomonosova, 29-31 maya 


\section{Экономическое управление}

2012 g.Materialy v 3 ch.:Chast' 1.-M.: Izdatel'stvo Moskovskogo universiteta, 2013.-736 s.-(materialy konferentsii).

12. Glushchenko V.V. Grazhdanologiya: vvedenie v teoriyu grazhdanskogo obshchestva - M.: IP Glushchenko Valerii Vladimirovich, 2009.-64 s.

13. Manoilo A.V. Siriiskii tupik «Arabskoi vesny». // Vestn. Mosk. Un-ta. Ser. 12. Politicheskie nauki. 2013. №6. S. 49-56.

14. Manoilo A.V. Mirnoe razreshenie konfliktov: natsional'nye kontseptsii, modeli, tekhnologii // Vlast'.2008.-№8. - S.79-84.

15. Manoilo A.V. Psikhologicheskie operatsii: modeli i tekhnologii upravleniya konfliktami. //Natsional'naya bezopasnost' nota bene. - 2009.-№1. - S.66-71.

16. Codagnone S., Filippov V. Equity, exit end national identity in a multinational federation: the "multicultural constitutional patriotism" project in Russia. // Journal of ethnic and migration studies. 2000. V. 26. №2.. P. 263-288.

17. Filippov V.R. Dogovornaya federatsiya i eksklyuzivnaya etnichnost' // Federalizm. 2002. №4. S. $185-216$

18. I. V. Surma, V. I. Anikin Sovremennaya Rossiya: metodologicheskie aspekty strategii politicheskogo i ekonomicheskogo razvitiya // Natsional'naya bezopasnost' / nota bene. - 2012. - 3. - C. 4 - 16.

19. A. G. Koryakov Rol' gosudarstva v obespechenii ustoichivogo razvitiya otraslei ekonomiki // Natsional'naya bezopasnost' / nota bene. - 2012. - 4. - C. 4 - 12.

20. Yanik A.A. Upravlenie sotsial'no-ekonomicheskimi izmeneniyami v usloviyakh krizisa: chto mozhet dat' Rossii opyt Kitaya? // Pravo i politika. - 2014. - 12. - C. 1840 - 1848. DOI: 10.7256/1811-9018.2014.12.12940.

21. Abramov R.A. Regional'naya promyshlennaya politika $v$ strukture ustoichivogo funktsionirovaniya territorii. // Politika i Obshchestvo. - 2015. - 3. - C. 345 - 353. DOI: 10.7256/1812-8696.2015.3.14513.

22. Nemtsev I.A. Strategiya ustoichivogo razvitiya kak integratsionnoe yadro Evraziiskogo soyuza // Politika i Obshchestvo. - 2015. - 2. - C. 198 - 213. DOI: 10.7256/1812-8696.2015.2.12298. 